\title{
Acetaldehyde at a Low Concentration Synergistically Exacerbates Allergic Airway Inflammation as an Endocrine-Disrupting Chemical and as a Volatile Organic Compound
}

\author{
Tetsuya Kawano Hiroto Matsuse Susumu Fukahori Tomoko Tsuchida \\ Tomoya Nishino Chizu Fukushima Shigeru Kohno \\ Second Department of Internal Medicine, Nagasaki University School of Medicine, Nagasaki, Japan
}

\section{Key Words}

Acetaldehyde $\cdot$ Allergic airway inflammation - Asthma bronchiale $\cdot$ Endocrine-disrupting chemical(s) $\cdot$ Volatile organic compound(s)

\begin{abstract}
Background: Acetaldehyde is an endocrine-disrupting chemical (EDC) and a volatile organic compound (VOC). It is also a carcinogen and teratogen that causes bronchoconstriction in a subset of asthmatics. However, the mechanism through which acetaldehyde acts as an EDC/VOC causing allergic airway inflammation remains unknown. Objectives: To determine the effects of a low concentration of acetaldehyde, which itself did not trigger airway inflammation, on extant allergic airway inflammation in a murine model of allergic asthma. Methods: We compared airway hyperresponsiveness (AHR), lung pathology, serum IgE and airway concentrations of cytokines among four groups of BALB/c mice [control, Dermatophagoides farinae (Df) allergen-sensitized (AS), intranasally acetaldehyde-injected (ALD) and AS-ALD mice]. Results: Physiological and histological differences were not evident between ALD and control mice. AS mice developed AHR and allergic airway inflammation characterized by goblet cell hyperplasia and eosinophilic infiltration. Both AHR and airway eosinophilia were significantly en-
\end{abstract}

hanced in AS-ALD compared with AS mice. Serum total and $D f$-specific IgE were significantly increased in both AS and AS-ALD mice compared with control and ALD mice, but comparable between AS and AS-ALD mice. Mite allergen sensitization significantly increased interleukin-5 and granulocyte macrophage colony-stimulating factor, and decreased interferon- $\gamma$ levels in the airways; injecting acetaldehyde into airways with allergic inflammation significantly increased the levels of these inflammatory cytokines. Conclusions: Exposure to acetaldehyde can enhance allergic airway inflammation in asthma.

Copyright $\odot 2012$ S. Karger AG, Basel

\section{Introduction}

Endocrine-disrupting chemicals (EDCs) confer health risks such as toxicity, carcinogenicity, mutagenicity, immunotoxicity and neurotoxicity in humans [1-5]. A relationship between EDCs and allergic diseases has been established [6-10], but the exact mechanism underlying this relationship remains obscure. Volatile EDCs are generally referred to as volatile organic compounds (VOCs). Exposure to VOCs such as formaldehyde or acetaldehyde can cause sick building syndrome or bronchial asthma [6-10].

\section{KARGER}

Fax +4161306 1234

E-Mail karger@karger.ch

www.karger.com
(C) 2012 S. Karger AG, Basel

$0025-7931 / 12 / 0842-0135 \$ 38.00 / 0$

Accessible online at:

www.karger.com/res
Hiroto Matsuse, MD

Second Department of Internal Medicine

Nagasaki University School of Medicine

1-7-1 Sakamoto, Nagasaki 852-8501 (Japan)

Tel. +81 95819 7273, E-Mail hmatsuse@ nagasaki-u.ac.jp 
Bronchial asthma is characterized by chronic airway inflammation and airway hyperresponsiveness (AHR) [11-15]. Among the various inflammatory cells, type $2 \mathrm{~T}-$ helper lymphocytes (Th2), which produce Th2 cytokines that regulate allergic airway inflammation, are typically located in the airways of asthma patients [12]. In particular, the Th2 cytokine interleukin (IL)-5 promotes the maturation and activation of eosinophils [11-15]. The type 1 T-helper lymphocyte (Th1) cytokine interferon (IFN)- $\gamma$ inhibits the biological effects of Th2 cytokines. Th2 immunity is dominant over Th1 immunity in asthma $[11,12]$. The most common trigger of acute exacerbation of asthma among both children and adults is viral respiratory tract infection [16]. Although the precise underlying mechanism of virus-induced asthma exacerbation remains unknown, viral infection probably exacerbates Th2-dominant allergic airway inflammation [11, $16]$.

Several other factors can exacerbate asthma. We previously reported that alcohol consumption exacerbates asthma in about half of the Japanese patients with asthma [17-19]. Acetaldehyde, a metabolite of alcohol, plays a critical role in this alcohol-induced bronchoconstriction via stimulation of mast cells/basophils to produce histamine [20]. In addition to being an alcohol metabolite, acetaldehyde is also a VOC that has been linked to sick building syndrome and asthma [6-10], and it might have various adverse effects on humans [1-5]. In fact, acetaldehyde in cigarette smoke inhibits ciliary motility via phosphokinase C-dependent mechanisms [21]. Taken together, these findings indicate that acetaldehyde affects airway inflammation as a VOC. Nonetheless, little is known about interactions between acetaldehyde and allergic airway inflammation. The present study investigates the effects of acetaldehyde as an EDC/VOC on extant allergic airway inflammation induced by mite allergens in a novel murine model of asthma.

\section{Materials and Methods}

\section{Acetaldehyde Concentration}

The concentration of acetaldehyde used herein was determined by preliminary experiments based on published findings $[22,23]$. Various concentrations of acetaldehyde were injected intranasally into mice daily for 1 week as described below and then lung specimens were histologically evaluated. We concluded that $50 \mu \mathrm{g}$ of acetaldehyde does not directly damage murine airways since this dose neither caused tissue damage nor inflammatory changes in this model. This concentration was lower than that used in a previous study of humans [23].
Animals and Immunization Protocol

An animal model of mite allergen-sensitized asthma was generated $[24,25]$. Four groups ( $n=8$ per group) of 4 - to 6 -weekold female BALB/c mice (Charles River Japan, Yokohama, Japan) were housed at the Laboratory Animal Center for Biochemical Research, Nagasaki University School of Medicine. All mice were immunized twice intraperitoneally on days 1 and 14 with $0.5 \mathrm{mg}$ of Dermatophagoides farinae ( $\mathrm{f} f$, American house dust mite, LG-5339; Cosmo Bio, Tokyo, Japan) per mouse precipitated in aluminum hydroxide. These mice were then challenged intranasally with $50 \mu \mathrm{l}$ of phosphate-buffered saline (PBS) [control group and acetaldehyde inoculated group (ALD)] or with 50 $\mu \mathrm{g}$ of $D f$ allergen $/ 50 \mu \mathrm{l}$ [allergen-sensitized group (AS) and ASALD group] on days 14, 16 and 18 [25]. The ALD and AS-ALD groups were each intranasally injected with $50 \mu \mathrm{g}$ of acetaldehyde (Sigma, St. Louis, Mo., USA) from days 14-20. We determined AHR on day 20 in unrestrained mice using whole-body plethysmography. All mice were sacrificed by dislocation of the cervical vertebrae on day 21 and peripheral blood was collected. Bronchoalveolar lavage fluid (BALF) was obtained from half of the mice in each group using $0.5 \mathrm{ml}$ of ice-cold PBS. Lung tissue samples were obtained from the other half of each group of mice for pathological evaluation. The procedures were reviewed and approved by the Nagasaki University School of Medicine Committee on Animal Research. All experiments were repeated at least three times.

\section{Determination of $A H R$}

We measured airway responsiveness to inhaled methacholine (MCh; Sigma) in unrestrained mice using whole-body plethysmography (PULMOS-I; M.I.P.S., Osaka, Japan) [25] to determine AHR in this model. AHR is expressed as calculated specific airway resistance $\left(\mathrm{sR}_{\mathrm{aw}}\right)$, which closely correlates with pulmonary resistance measured using conventional two-chamber plethysmography in ventilated animals. The four murine groups were exposed to PBS for $5 \mathrm{~min}$ and subsequently to increasing concentrations $(6,12,25$ and $50 \mathrm{mg} / \mathrm{ml})$ of $\mathrm{MCh}$ in PBS using an ultrasonic nebulizer (NE-U17; Omron, Kyoto, Japan). We then calculated $s R_{a w}$ values from recordings taken for $3 \mathrm{~min}$ after each dose.

\section{Pathological Evaluation of Pulmonary Inflammation}

Lung sections from each group were stained with hematoxylin and eosin and evaluated (magnification $\times 400$ ) at least three times by three observers in a blinded fashion [25]. The number of eosinophils and the total number of nuclei in three randomly selected airway samples were determined. Eosinophils were reported as percentage of the total cells in the airways.

\section{Determination of Serum IgE Levels}

Serum concentrations of total $\operatorname{IgE}$ and $D f$-specific $\operatorname{IgE}$ were measured in duplicate using enzyme-linked immunosorbent assays (ELISA). Total serum IgE concentrations were determined using a rat anti-mouse IgE antibody (Ab; PharMingen, San Diego, Calif., USA) and biotin-conjugated rat anti-mouse $\operatorname{IgE} \mathrm{mAb}$ (PharMingen) [20]. Other 96-well ELISA plates were coated overnight at $4^{\circ} \mathrm{C}$ with $5 \mu \mathrm{g} / \mathrm{ml}$ of $D f$ extract to measure $D f$-specific IgE. Serum samples (1:10) were incubated for $2 \mathrm{~h}$ at room temperature in the $D f$-coated plates before incubation with biotin- 
conjugated rat anti-mouse $\operatorname{IgE} \mathrm{mAb}$. The optical density at 405 $\mathrm{nm}\left(\mathrm{OD}_{405}\right)$ was determined using an automatic ELISA plate reader. The total serum IgE level (expressed as $\mu \mathrm{g} / \mathrm{ml}$ ) was determined using a mouse IgE standard (PharMingen). The $D f$-specific serum IgE levels are expressed as $\mathrm{OD}_{405}$.

\section{Analysis of $B A L F$}

We evaluated BALF samples using a hemocytometer and light microscopy. Each BALF sample was centrifuged for $10 \mathrm{~min}$ at $400 \mathrm{~g}$ at $4^{\circ} \mathrm{C}$, and cytokines were analyzed in the supernatants. The cell pellets were resuspended in $1 \mathrm{ml}$ of PBS. The total number of cells in the BALF was counted using a hemocytometer, and cells on Cytospin slides were fixed and visualized by May-Giemsa staining. Three observers performed differential counts of 200 cells. Absolute cell numbers were calculated as the product of the total and differential cell counts, and the absolute number of eosinophils in the BALF was calculated. The concentrations of IFN$\gamma$, IL-5 and granulocyte macrophage colony-stimulating factor (GM-CSF) in the BALF supernatants were determined by ELISA (Quantikine; R\&D Systems, Minneapolis, Minn., USA), as described by the manufacturer.

\section{Statistical Analysis}

Results are expressed as means \pm SEM. Data were evaluated using repeated-measure ANOVA with a Bonferroni multiple comparison test. A value of $\mathrm{p}<0.05$ was considered significant.

\section{Results}

\section{Acetaldehyde Enhanced AHR in a Murine Model of Asthma}

We measured airway responsiveness to inhaled $\mathrm{MCh}$ (fig. 1). The $s \mathrm{R}_{\mathrm{aw}}$ value did not significantly increase in response to $\mathrm{PBS}$ inhalation in any group, but significantly increased in the AS and AS-ALD groups compared with the control group after inhaling 25 and $50 \mathrm{mg} / \mathrm{ml}$ of $\mathrm{MCh}$, indicating AHR in this animal model of bronchial asthma. Acetaldehyde at this concentration did not result in AHR. sR $\mathrm{R}_{\mathrm{aw}}$ significantly increased in the AS-ALD compared with the AS group after inhaling $50 \mathrm{mg} / \mathrm{ml}$ of $\mathrm{MCh}$. These results suggest that acetaldehyde at this concentration enhanced AHR.

\section{Low Acetaldehyde Concentration Worsened Airway Inflammation}

Figure $2 \mathrm{a}-\mathrm{d}$ shows representative pathological features of the four groups of mice. Airway inflammation was not significantly increased in ALD compared with control mice. Goblet cell metaplasia and cellular infiltrate with eosinophils were identified in AS mice. The mean number of infiltrating eosinophils per 10 perivascular areas was significantly increased in AS-ALD compared with AS mice (means \pm SEM: $38.7 \pm 12.1$ vs. $22.1 \pm 9.7$,

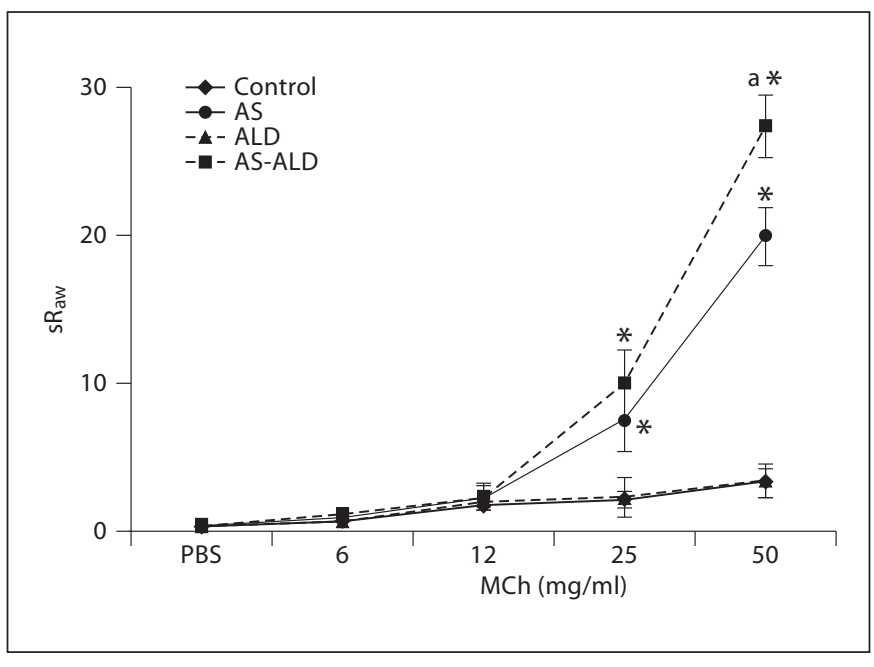

Fig. 1. Mouse airway responsiveness to inhaled MCh. AS mice developed AHR, whereas control and ALD mice did not. AHR was more severe in AS-ALD mice than in AS mice. Means \pm SEM of $\mathrm{sR}_{\mathrm{aw}}$ values to inhaled $\mathrm{MCh}(\mathrm{n}=8 /$ group $) .{ }^{*} \mathrm{p}<0.01 \mathrm{vs}$. control, ${ }^{a} \mathrm{p}<0.05$ vs. AS.

$\mathrm{p}<0.05)$. Analysis of the cellular components of BALF revealed significantly more lymphocytes and eosinophils in the airways of AS than in control mice, and airway eosinophilia was significantly increased in AS-ALD compared with AS mice (fig. 2e).

\section{Acetaldehyde Did Not Change Serum IgE Levels}

Figure 3 shows serum total IgE and $D f$-specific IgE levels. These values were significantly increased in AS and AS-ALD compared with control and ALD mice. Total IgE or $D f$-specific IgE did not significantly differ between control and ALD mice.

\section{Acetaldehyde Increased Inflammatory Cytokine Concentrations in $B A L F$}

Figure 4 shows IL-5, GM-CSF and IFN- $\gamma$ levels in BALF. Like the pathological lung profile, the cytokine profile was not significantly altered in ALD mice compared with control mice, whereas IL-5 and GM-CSF were significantly increased, and IFN- $\gamma$ was significantly decreased in AS compared with control mice. Levels of IL-5, GM-CSF and IFN- $\gamma$ were significantly increased in ASALD compared with AS mice, and a low dose of acetaldehyde significantly increased inflammatory cytokine levels in AS mice. 
Fig. 2. Representative photomicrographs $(\times 400)$ of lung tissue samples from four groups of mice $(\mathbf{a}-\mathbf{d})$, and cell counts in $\operatorname{BALF}(\mathbf{e})$. a Control. b AS. c ALD. d ASALD. Eosinophilic airway inflammation and acetaldehyde further exacerbated allergic airway inflammation in AS mice (d). Acetaldehyde alone did not cause histological changes in murine lungs at this concentration (c). Lymphocyte and eosinophil numbers are significantly increased in BALF from AS and AS-ALD groups compared with that from the control group. Eosinophil count significantly increased in AS-ALD compared with the AS group (e); ${ }^{*} \mathrm{p}<0.01$ vs. control, ${ }^{\mathrm{a}} \mathrm{p}<0.01$ vs. AS.
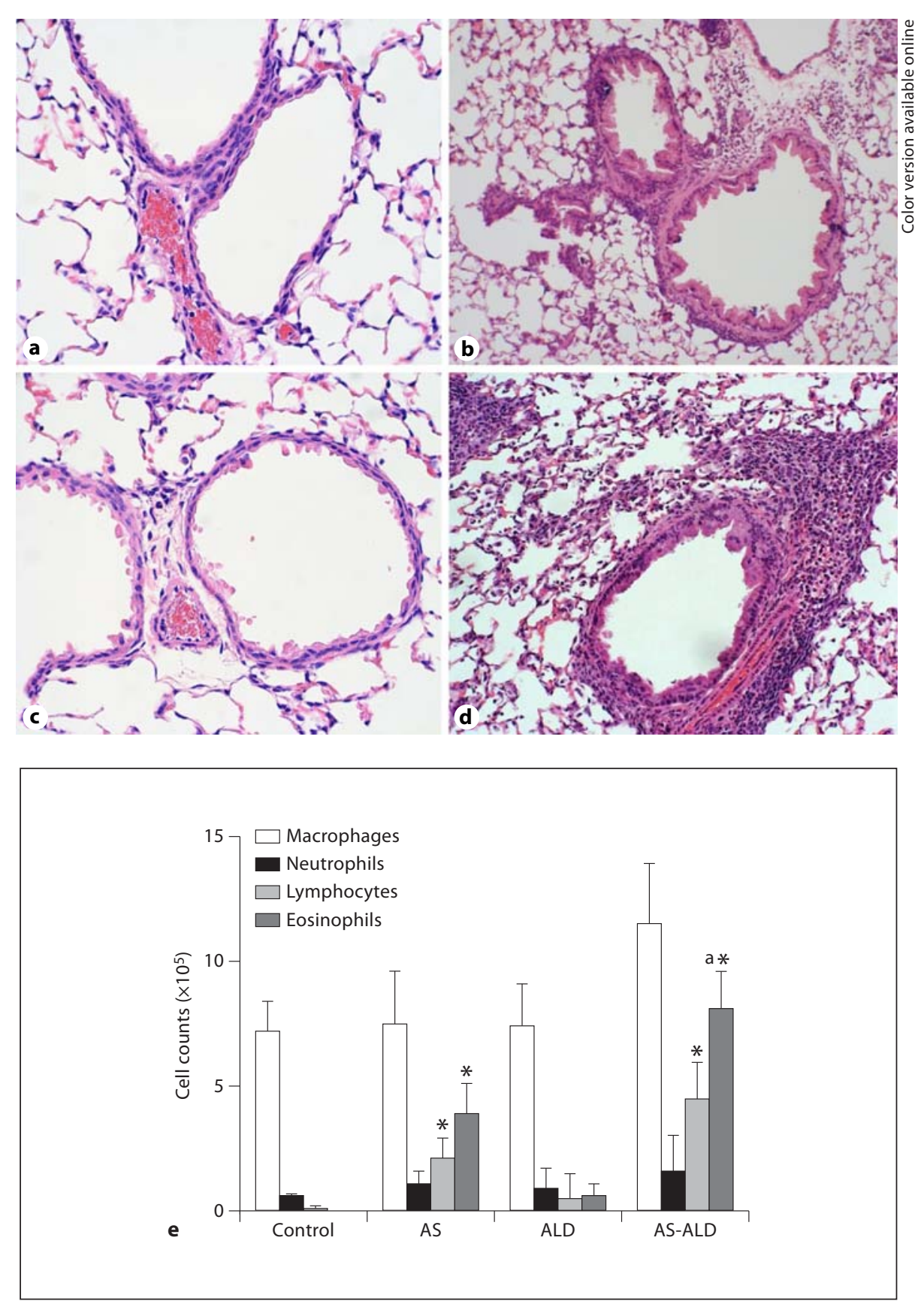

\section{Discussion}

The major findings of the present study are as follows. Intranasal injection of a low concentration of acetaldehyde, which itself did not trigger airway inflammation, worsened AHR, significantly exacerbated extant allergic airway inflammation induced by mite allergens and in- creased the production of Th1 and Th2 cytokines. Acetaldehyde is commonly encountered in the environment. Cigarette smoke and vehicle exhaust emissions contain both acetaldehyde and formaldehyde [2, 6-8, 21], and these chemicals are also found in paints, plastic products and adhesives, for example $[2,7,9]$. In addition, some fruits naturally contain acetaldehyde [2], and acetalde- 


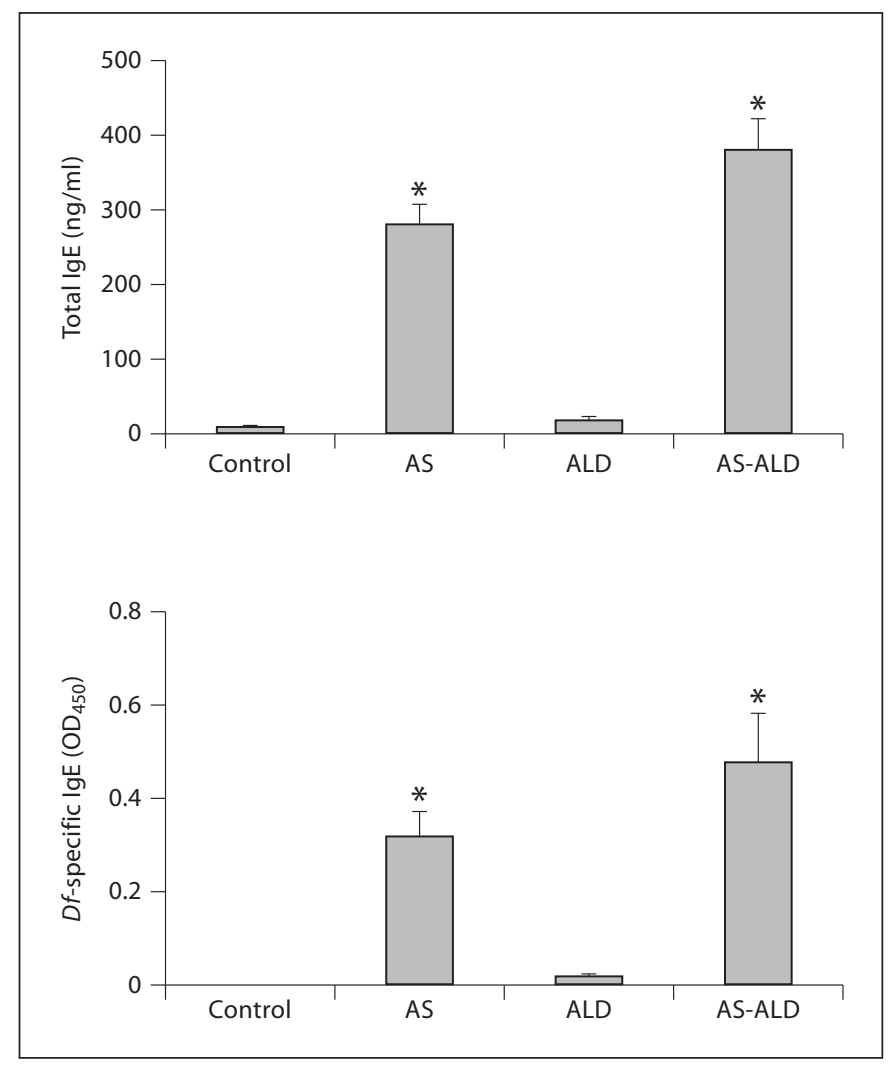

Fig. 3. Serum levels of total and $D f$-specific IgE were significantly increased in AS and AS-ALD groups compared with the control group. Acetaldehyde did not additively affect serum IgE; ${ }^{*} \mathrm{p}<0.01$ vs. control.

hyde is used as a food additive in some countries. Therefore, continuous exposure to environmental acetaldehyde or formaldehyde might exacerbate asthma. Many reports have described that formaldehyde acts as an EDC/ VOC and adversely affects health [1-10]. Garrett et al. [7] found that inoculation with low levels of formaldehyde increases the risk of bronchial asthma in children. Exposure to low levels of formaldehyde also increases IgE levels in humans [26] and mice [10]. Allergic sensitization to inhaled allergens is enhanced in Guinea pigs exposed to formaldehyde [27]. However, the effects of low acetaldehyde (as an EDC/VOC) concentrations on allergic airway inflammation has not been reported in detail.

Acetaldehyde can trigger acute exacerbations of asth$\mathrm{ma}$ as it is also a metabolite of alcohol [17-20,28]. About half of Japanese patients with asthma have experienced exacerbation after alcohol consumption. In the peripheral blood of many Japanese people, acetaldehyde concentrations are increased after alcohol consumption be-
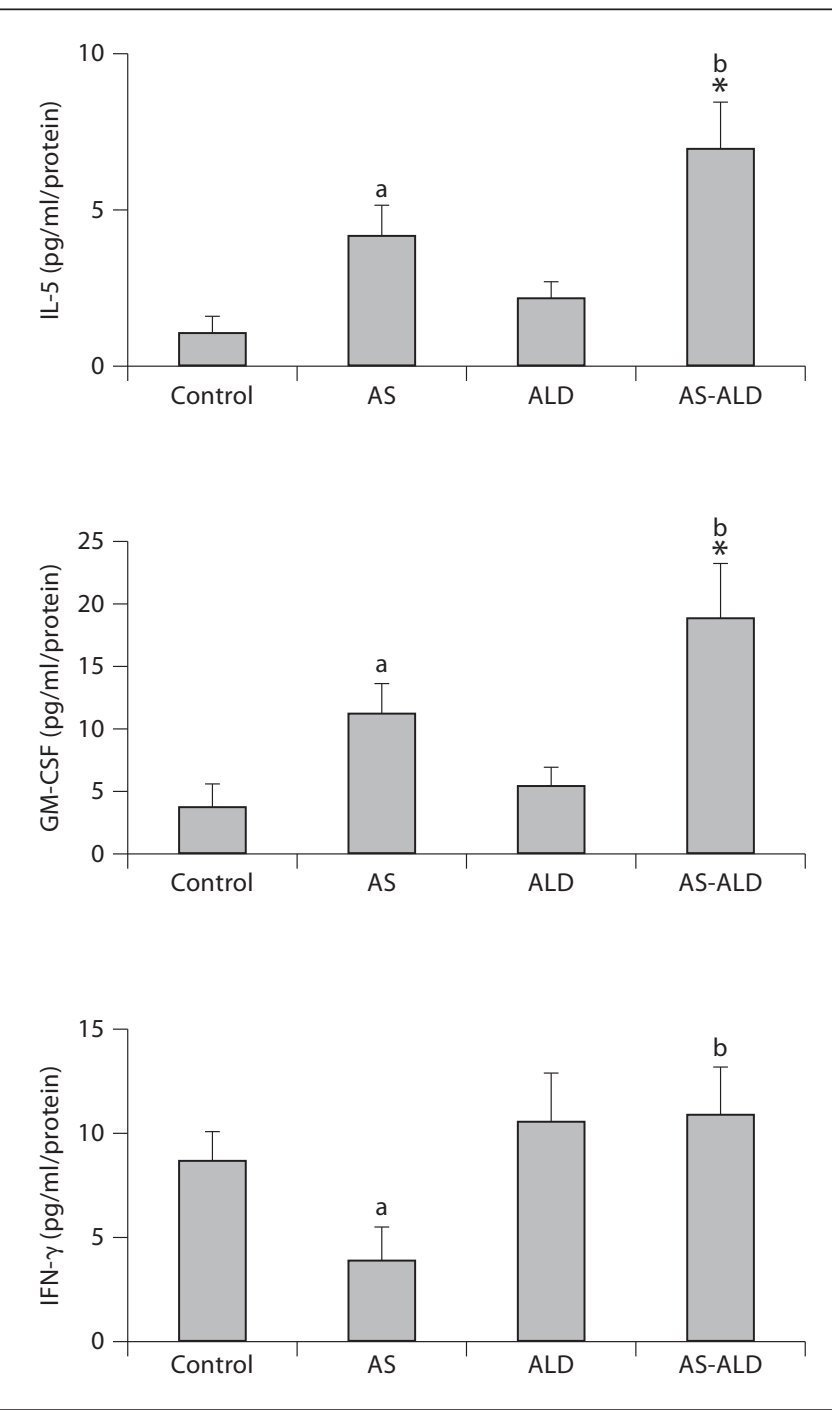

Fig. 4. Cytokine concentrations in the BALF did not significantly change between control and ALD groups. IL-5 and GM-CSF levels were significantly increased in AS compared with control mice, and IL-5 and GM-CSF were significantly increased in ASALD compared with AS mice. IFN- $\gamma$ was significantly decreased in AS compared with control mice and significantly increased in AS-ALD mice; ${ }^{*} \mathrm{p}<0.01,{ }^{\mathrm{a}} \mathrm{p}<0.05$ vs. control, ${ }^{\mathrm{b}} \mathrm{p}<0.05$ vs. AS.

cause of genetically lower levels or absent activity of aldehyde dehydrogenase 2, a primary enzyme involved in acetaldehyde metabolism [17-20]. We previously confirmed that an increased blood acetaldehyde concentration stimulates human mast cells in bronchi to release histamine, thus causing bronchoconstriction [17-20]. The present findings suggest that acetaldehyde has a proinflammatory effect in the pathophysiology of asthma in addition to a bronchoconstrictive effect. 
The immunological effects of alcohol on infectious diseases have received increased attention [29]. In fact, alcoholism is considered a risk factor for infections such as pneumonia [30]. A growing body of evidence points to alcohol as an important modifier of mucociliary clearance, which is the first line of defense in the lungs [28]. Acetaldehyde activates phosphokinase $\mathrm{C}$ in airway cells and might be linked to the release of airway oxidants [21]. Aytacoglu et al. [31] reported that alcohol could cause lung damage. In contrast, little is known about interactions between alcohol and allergic inflammation. One mechanism through which inhaled acetaldehyde might enhance allergic airway inflammation is physical damage to the airway epithelium, which would enhance the penetration of mite allergens into the airways, resulting in an increased IgE response. However, this was not proven in the present study. Clarisse et al. [32] measured indoor air concentrations of aldehydes and found very low levels. The combustion of cigarettes remarkably increases airborne aldehyde concentrations [33]. Thus, smoking tobacco increases the amount of exposure to acetaldehyde compared with the low concentration generated in the present study, in which levels of mite allergen-specific IgE antibody were comparable between AS and AS-ALD mice. We previously disclosed that acetaldehyde, but not alcohol, stimulates GM-CSF production from the airway epithelium in vitro through the activation of nuclear factor (NF)- $\mathrm{kB}$ in lung tissue from patients with lung cancer [34]. The present study also demonstrated that a low concentration of acetaldehyde significantly increased airway production of GM-CSF induced by mite allergen in vivo. Since GM-CSF is a growth factor for dendritic cells that serve as the primary antigen-presenting cells in the airways, the present findings suggest that the maturation of dendritic cells by acetaldehyde-induced GM-CSF production enhances adaptive immunity and thus exacerbates allergic airway inflammation. Although the mechanism of acetaldehyde-increased GM-CSF production remains uncertain, the present findings indicate that acetaldehyde can exacerbate allergic airway inflammation via an EDC pathway.

In conclusion, acetaldehyde might be involved in the pathogenesis of asthma via two pathways. One is that increased blood levels of acetaldehyde, which may be due to genetically reduced or lack of aldehyde dehydrogenase 2 activity in some Asian populations, stimulate mast cells to release histamine after oral alcohol intake, and this causes bronchoconstriction. The other is that inhaled acetaldehyde acting as an EDC enhances allergic airway inflammation.

\section{References}

1 Yang M, Park MS, Lee HS: Endocrine disrupting chemicals: human exposure and health risks. J Environ Sci Health C Environ Carcinog Ecotoxicol Rev 2006;24:183-224.

$\checkmark 2$ Whaley DA, Keyes D, Khorrami B: Incorporation of endocrine disruption into chemical hazard scoring for pollution prevention and current list of endocrine disrupting chemicals. Drug Chem Toxicol 2001;24:359-420.

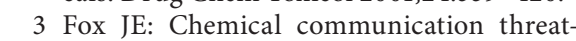
ened by endocrine-disrupting chemicals. Environ Health Perspect 2004;112:648-653.

$\checkmark 4$ Choi SM, Yoo SD, Lee BM: Toxicological characteristics of endocrine-disrupting chemicals: developmental toxicity, carcinogenicity, and mutagenecity. J Toxicol Environ Health B Crit Rev 2004;7:1-24.

5 Safe S: Clinical correlates of environmental endocrine disruptors. Trends Endocrinol Metab 2005;16:139-144.

6 Arif AA, Shah SM: Association between personal exposure to volatile organic compounds and asthma among US adult population. Int Arch Occup Environ Health 2007; 80:711-719.
7 Garrett MH, Hooper MA, Hooper BM, Rayment PR, Abramson MJ: Increased risk of allergy in children due to formaldehyde exposure in homes. Allergy 1999;54:330-337.

$\checkmark 8$ Pappas GP, Herbert RJ, Henderson W, Koenig J, Stover B, Barnhart S: The respiratory effects of volatile organic compounds. Int J Occup Environ Health 2000;6:1-8.

$\checkmark 9$ Kim WJ, Terada N, Nomura T, Takahashi R, Lee SD, Park JH, Konno A: Effect of formaldehyde on the expression of adhesion molecules in nasal microvascular endothelial cells: the role of formaldehyde in the pathogenesis of sick building syndrome. Clin Exp Allergy 2002;32:287-295.

$\checkmark 10$ Tarkowski M, Gorski P: Increased IgE antiovalbumin level in mice exposed to formaldehyde. Int Arch Allergy Immunol 1995; 106 : 422-424.

11 Busse WW, Lemanske RF: Asthma (review). N Engl J Med 2001;344:350-362.

12 Paul WE, Seder RA: Lymphocyte responses and cytokines. Cell 1994;76:241.

13 Pelikan Z: Delayed asthmatic response to bronchial challenge with allergen-mediators, eicosanoids, eosinophil and neutrophil constituents in the blood and urine. Respiration 2011;82:225-236.
14 Zietkowski Z, Skiepko R, Tomasiak-Lozowska MM, Bodzenta-Lukaszyk A: Anti-IgE therapy with omalizumab decreases endothelin-1 in exhaled breath condensate of patients with severe persistent allergic asthma. Respiration 2010;80:534-542.

15 Tomari S, Matsuse H, Hirose H, Tsuchida T, Fukahori S, Fukushima C, Kawano T, Matsuo N, Kohno S: Observational study of the additive effects of pranlukast on inflammatory markers of clinically stable asthma with inhaled corticosteroids and long-acting beta 2 agonists. Respiration 2008;76:398-402.

16 Busse WW, Lemanske RF Jr, Gern JE: Role of viral respiratory infections in asthma and asthma exacerbations. Lancet 2010;376:826834.

17 Shimoda T, Kohno S, Takao A, Fujiwara C, Matsuse H, Sakai H, Watanabe T, Hara K, Asai S: Investigation of the mechanism of alcohol-induced bronchial asthma. J Allergy Clin Immunol 1996;97:74-84.

18 Takao A, Shimoda T, Matsuse H, Mitsuta K, Obase Y, Asai S, Kohno S: Inhibitory effects of azelastine hydrochloride in alcohol-induced asthma. Ann Allergy Asthma Immunol 1999;82:390-394. 
19 Matsuse H, Shimoda T, Fukushima C, Mitsuta K, Kawano T, Tomari S, Saeki S, Kondoh Y, Machida I, Obase Y, Asai S, Kohno S: Screening for acetaldehyde dehydrogenase 2 genotype in alcohol-induced asthma by using the ethanol patch test. J Allergy Clin Immunol 2001;108:715-719.

20 Kawano T, Matsuse H, Kondo Y, Machida I, Saeki S, Tomari S, Mitsuta K, Obase Y, Fukushima C, Shimoda T, Kohno S: Acetaldehyde induces histamine release from human airway mast cells to cause bronchoconstriction. Int Arch Allergy Immunol 2004;134:233239.

21 Elliott MK, Sisson JH, Wyatt TA: Effects of cigarette smoke and alcohol on ciliated tracheal epithelium and inflammatory cell recruitment. Am J Respir Cell Mol Biol 2007; 36:452-459.

22 Myou S, Fujimura M, Kita T, Katayama N, Abo M, Yoshimi Y, Nishituji M, Nomura S, Nakao S: Sensory neuropeptides are not involved in acetaldehyde-induced bronchoconstriction in guinea-pigs. J Auton Pharmacol 2001;21:139-143.

-23 Prieto L, Sanchez-Toril F, Gutierrez V, Marin MJ: Airway responsiveness to inhaled acetaldehyde in subjects with allergic rhinitis: relationship to methacholine responsiveness. Respiration 2002;69:129-135.
24 Matsuse H, Behera AK, Kumar M, Rabb H, Lockey RF, Mohapatra SS: Recurrent respiratory syncytial virus infections in allergensensitized mice lead to persistent airway inflammation and hyperresponsiveness. J Immunol 2000;164:6583-6592.

25 Kawano T, Matsuse H, Kondo Y, Machida I, Saeki S, Tomari S, Mitsuta K, Obase Y, Fukushima C, Shimoda T, Kohno S: Cysteinyl leukotrienes induce nuclear factor kappa B activation and RANTES production in a murine model of asthma. J Allergy Clin Immunol 2003;112:369-374.

26 Wantke F, Demmer CM, Tappler P, Gotz M, Jarish R: Exposure to gaseous formaldehyde induces IgE-mediated sensitization to formaldehyde in school-children. Clin Exp Allergy 1996;26:276-280.

27 Riedel F, Hasenauer E, Barth PJ, Koziorowski A, Rieger CH: Formaldehyde exposure enhances inhalative allergic sensitization in the guinea pig. Allergy 1996;51:94-99.

28 Sisson JH: Alcohol and airways function in health and disease. Alcohol 2007;41:293307.

29 Diaz LE, Montero A, Gonzalez-Gross M, Vallejo AI, Romeo J, Marcos A: Influence of alcohol consumption on immunological status: a review. Eur J Clin Nutr 2002;56:S50S53.
0 Zhang P, Bagby GJ, Happel KI, Raasch CE, Nelson S: Alcohol abuse, immunosuppression, and pulmonary infection. Curr Drug Abuse Rev 2008;1:56-67.

31 Aytacoglu BN, Calikoglu M, Tamer L, Coskun B, Sucu N, Kose N, Aktas S, Dikmengli M: Alcohol-induced lung damage and increased oxidative stress. Environ Int 2011;37:743-765.

32 Clarisse B, Laurent AM, Seta N, Le Moullec Y, EI Hasnaoui A, Momas I: Indoor aldehydes: measurement of contamination levels and identification of their determinants in Paris dwellings. Environ Res 2003;92:245253.

33 Sarigiannis DA, Karakitsios SP, Gotti A, Liakos IL, Katsoyiannis A: Exposure to major volatile organic compounds and carbonyls in European indoor environments and associated health risk. Environ Int 2011;37:743765.

34 Machida I, Matsuse H, Kondo Y, Kawano T, Saeki S, Tomari S, Fukushima C, Shimoda T, Kohno S: Acetaldehyde induces granulocyte macrophage colony-stimulating factor production in human bronchi through activation of nuclear factor-kappa B. Allergy Asthma Proc 2003;24:367-371. 